\title{
Training the Non-Specialist Music Teacher: Insights from an Indonesian Action Research Study
}

\author{
J. Julia*, Tedi Supriyadi, Prana Dwija Iswara \\ Elementary School Teacher Education, Universitas Pendidikan Indonesia, Indonesia \\ Received December 4, 2019; Revised January 8, 2020; Accepted January 16, 2020
}

Copyright $\odot 2020$ by authors, all rights reserved. Authors agree that this article remains permanently open access under the terms of the Creative Commons Attribution License 4.0 International License

\begin{abstract}
To improve non-specialist music teachers' knowledge and skills in teaching music, they need training to re-understand the teaching materials and to change their way of teaching music to avoid errors in applying music practices to students. This research report exemplifies collaborative work in making critical-reflective stages and applying each stage to elementary school teachers through training programs in an action research. The results indicated that non-specialist music teachers were able to develop their knowledge of basic music theory as teaching material and to develop skills in using media and applications supporting music teaching. The training of teachers and providing information about the impact of their teaching ways to the students' future musical competence were able to change the way they teach music. Teachers need to be given good attention, such as by providing development programs from the government so that the process and effectiveness of teaching music can be improved continuously.
\end{abstract}

Keywords Training, Music Teacher, Elementary School, Non-Specialist Music Teacher, Music Teacher Competency

\section{Introduction}

Elementary school music teachers in Indonesia are faced with a problematic situation. On one hand they have to teach music based on the curriculum imposed by the government, both in terms of vocals and musical instruments. On the other hand, they were educated to become wholesale elementary school teachers hoped to be versatile in all subjects. In reality, they face difficulties in teaching music in accordance with the curriculum. This results in a lack of competence both in theory and practice in music. This condition is in contrast to secondary school level that has music teachers who are music education undergraduates.

The impact of the elementary school music education system is quite significant. Students do not get good music education such as the practice of vocal accuracy, tempo stability, notation reading, musical instrument learning, etc. (Apriani \& Julia, 2019; J Julia, Supriyadi, \& Iswara, 2019; Maulana \& Julia, 2019; Utama \& Julia, 2019). Meanwhile, research results showed that education or musical experience in elementary school age has a significant influence on the process of constructing students' musical competence (Hernández-Bravo, Cardona-Moltó, \& Hernández-Bravo, 2016; Vicente-Nicolás \& Mac Ruairc, 2014). Teachers complain about this condition but the education system is difficult to change because it depends on the policy makers. A solution that teachers can do is to follow training programs. Unfortunately, the results of a survey of elementary school teachers in Sumedang Regency, West Java Province, showed that the local education office (government) rarely hold training programs to improve teacher competency in music. Even in the last two years, there has been no training program. Seeing this condition, we took the initiative to hold a music training program for elementary school teachers hoping that they could improve their competencies and knowledge about music theory and skills in music teaching practice. Our proposal which was proposed to the university to organize music teaching training to elementary school teachers was approved for funding.

Previous research found how important are for the training programs and the support from the government. Hennessy (2017) did a research to improve the music teachers' competence and confidence in teaching. They were trained and received 21 training modules. However, the findings showed that the problems in preparing the teachers to teach music are not resolved. From an intervention, it was discovered that a small fund from the government can have a significant impact on the trainees. It was also found that trainers have difficulties to maintain work if the teacher training did genuinely seeks to train 
teachers for the whole curriculum. Many primary schools experience this matter this is the same issue which severely limits music education in many primary schools.

Barrett, Zhukov, and Welch (2019) reported evaluation results of a pilot program to mentor general classroom teachers about workplace music in 11 early childhood education institutions in Australia. The results showed that the mentoring got positive outcomes, enriched the schools' music curriculum, structured locally relevant programs, built resources, grows teacher music skills and confidence, and it impacted positively on student learning and behavior. This longitudinal mentoring with traditional approaches expanded to professional development for in-service music teachers through a collaborative approach.

Recent research on the efforts to improve music teacher competence in Indonesia has been conducted by J Julia, Hakim, and Fadlilah (2019). They conducted an action research to shift the elementary school teachers' understanding of the methods to teach songs to students. They revealed to the teachers the effect of not teaching the students to sing well and the research results showed that the teachers could change their understanding of teaching and used modern methods of teaching songs. Additionally, the teachers were guided to use various applications and media and that provided them new insights to choose teaching aids, and increase literacy on teaching vocals.

J. Julia, Isrokatun, Pramajati, Sukaesih, and Aisyah (2019) conducted a research to improve the ability of elementary school teacher candidates to read music notation. Their results showed that students' ability to read music notation could be improved through several stages of critical and reflective learning. The activities were, for example, by providing an understanding of the importance of reading music notation, analyzing music notation, and providing new experiences using music applications as a medium for learning music.

Unlike previous studies, this research analyzes the process and results of music training to non-specialist music teachers who teach music in elementary schools with a focus on changes in the way of teaching music. The research is action research using the principles of developing a sustainable process called a reflective-critical cycle. Two questions guided the implementation process, "Can elementary school teachers improve their competence to teach music? Can elementary school teachers change the way they teach music?" Thus, the purpose of this study is to improve the competence of elementary school teachers and change their way of teaching music.

\section{Theoretical Framework}

The main purpose of the elementary school music teacher training is to improve their competence and change their paradigm of teaching music. Shulman and Wilson (2005), Morrow (2007) and Thomasian (2007) views are followed by several experts of music teacher training, especially on important music content knowledge (Haston \& Leon-Guerrero, 2008; Si Millican, 2008; Wexler, 2009). In music, as a skills-based subject, the concept of content knowledge is essential to be delivered to grow specific basic music skills (Ballantyne, 2006; Millican, 2016). Flolu (2004), Choksy (2001) and Campbell, Campbell, and Dickinson (1999) all agreed that at before the music teacher candidates graduate, they should acquire sufficient music theories and practical competences. They must have the performance skills (singing, dancing, creating and playing instruments) and music listening and analysis skills (Georgii-Hemming \& Westvall, 2010; Lasauskiene \& Yang, 2017; Matonis, 2007; Péter, 2013).

Related to teaching skills, the researchers believe that successful music teachers can involve all learners during the learning process (Abril, 2011; Blackburn, 2000; Wiggins, 2007; Wright \& Kanellopoulos, 2010). This can be achieved by creating chances to demonstrate, explore and hands-on practice. To be effective music teachers, they must be able to facilitate learning experiences and develop concepts in a gradual approach that starts from a lower level to a higher level (Ballantyne, 2007; Rohwer \& Henry, 2004). Moreover they must be able to stimulate learners' imagination and creativity (Blackburn, 2000; Miksza, Roeder, \& Biggs, 2010; Teachout, 1997). There is also an opinion that says a music teacher should be able to detect errors in musical performance (Brand \& Burnsed, 1981; Byo, 1993, 1997; Collins, 1993; Katahira, Abla, Masuda, \& Okanoya, 2008; Maidhof, Rieger, Prinz, \& Koelsch, 2009). Several researchers also emphasizes on the importance of a good rapport with learners. They must be able to handle learners in a firm but fair manner, while at the same time give enjoyment, interest and participation (Bakker, 2005; Collins, 1993; Sheldon, 2001).

From musical pedagogy perspective, a teachers' musical competence in structure and content depends on their professional activity. Teachers should have a sense of rhythm and tuneful ear to be engaged in musical activities, (Abrahams, 2005; Garnett, 2013; Kovalev, Khussainova, Balagazova, \& Zhankul, 2016; Teplov, 1985). The personal-creative component of music-creative competence consists of professional self-awareness, self-knowledge and self-esteem, musical and creative thinking, self-regulation, self-reflection, self-realization and self-affirmation (Jarvin \& Subotnik, 2010; Kholodnaya, 2002; Tomlinson, 2012). The music performance competence is assessed by several criteria, such as the extent of musical abilities, emotional and volitional qualities, motivation and value orientations, development of the system of knowledge and skills, reflective performance readiness (McPherson \& McCormick, 2006; Sloboda, 2000; Vasilyeva, 2006). The teacher candidates' development of music performance competence is considered as controlled externally and self-regulating within a system approach (Anderson \& Denson, 2015; Dotger, Dekaney, \& Coggiola, 2019; 
Edelman, 2016; Groulx, 2016; Kuebel, 2017; Legette, 2013; Legette \& McCord, 2014; Parker, Bond, \& Powell, 2017).

Through training, the teachers were expected to get used to competitions. Teachers must be able to demonstrate practical and theoretical competence by showing that they can reflect action by monitoring their activities related to the standard of musical practice. Therefore the teacher can solve many musical problems (Carver, 2017; Delport \& Mufute, 2010b; Dibane, 2018; D. J. Elliott, 1995; J Julia, T Supriyadi, et al., 2019).

\section{Methods}

\subsection{Research Design and Collaborative Aspect}

This research uses action research design to gather information and then improve the way of work and ways of teaching and learning of the research subjects (Creswell, 2015; Kemmis \& McTaggart, 2005; Kemmis, McTaggart, \& Nixon, 2014; McTaggart, 1994). Action research is a way to help teachers in training to take a stance in inquiry (Canrinus, Bergem, Klette, \& Hammerness, 2017; Kane \& Chimwayange, 2014; McQuillan, Welch, \& Barnatt, 2012). It is even considered as an embedded in the form of professional development for pre-service teachers (Ado, 2013; J. Elliott, 2015; Jayakumar, 2016; Mitits, 2018). Using action research, it is believed that teacher training participants can increase their enthusiasm and confidence (Louise \& Crawford, 2016; Pelton, 2010), find meaningful practices (Amin, Rashid, \& Teh, 2019; Kiss, 2016; Vo, Pang, \& Lee, 2018), develop their own identity, and foster a sense of belonging to the school community, especially for teachers candidates who can easily facilitate integration when placed in schools (Al-Mahdi, 2019; Amin et al., 2019).

In the research, we used collaborative work methods by involving several parties. Collaboration in action research can help researchers and teachers to develop research, solve problems, make decision, and build leadership skills, and make use of new teaching practices (Adams \& Townsend, 2014; Furtado \& Anderson, 2012; Gordon \& Solis, 2018; Henderson, 2017; Hines \& Conner-Zachocki, 2015; Sullivan \& Glanz, 2013; vanOostveen, 2017). An easy way to form a collaboration team is to publicize the project and see who is interested in participating in the project (Heil, 2005; J Julia \& Isrokatun, 2019). When this project was announced to several parties, many teachers were interested in joining this project, and there was one chairperson of a private educational program developer (private foundation) who was ready to collaborate and help to coordinate the teachers in each training schedule. Two colleagues were also willing to join the project and assist in preparing materials and learning tools/media for training.

\subsection{Research Site and Participants}

The research was conducted in Sumedang Regency, West Java. West Java Province consists of 27 regencies, and one of the regencies as the research location is Sumedang. This regency is divided into three areas based on their level of progress, namely urban, transitional and rural areas. This regency consists of 26 districts, and those who participated in the training were from 11 districts. All districts on average consist of rice fields and mountains. The research location is shown in Figure 1.

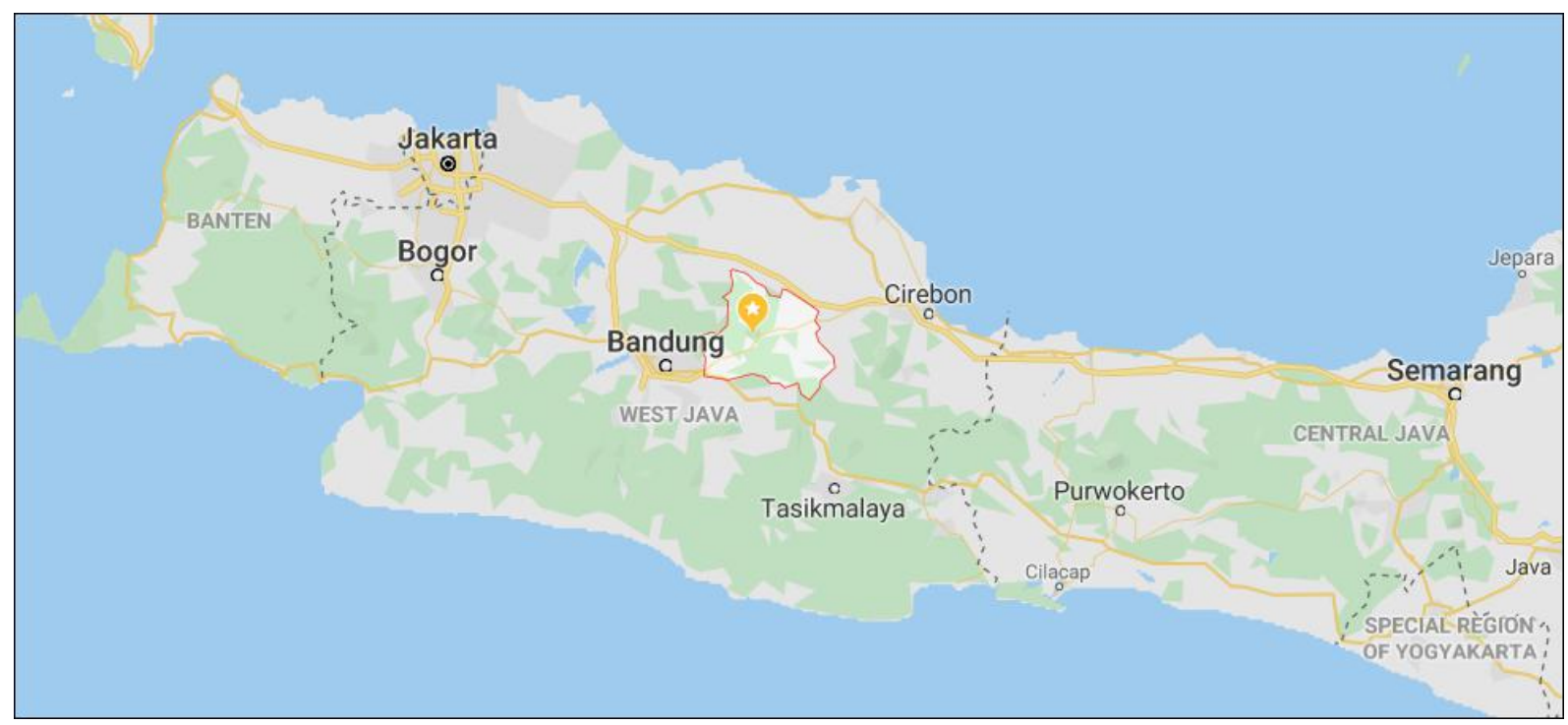

Note: Sumedang is in the red boundaries and the research location is marked by a star.

Figure 1. Research Site 
Participants involved in this training program were 54 people from 11 districts, consisting of nine $(16.7 \%)$ men and $45(83.3 \%)$ women. Three $(5.6 \%)$ people were aged between 21-30 years, 28 (51.9\%) people aged between 41-50 years, and $23(42.6 \%)$ people aged between 51-60 years. The length of time they have were quite varied, three (5.6\%) people had been teachers for $1-5$ years, one $(1.9 \%)$ had been a teacher for 6-10 years, $22(40.7 \%)$ people had become teachers for $11-15$ years, 20 (37\%) people for $16-20$ years, and eight (14.8\%) people for more than 20 years. As for their positions or assignments in the institution, they were quite diverse, among others, two (3.7\%) people had served as principals, $10(18.5 \%)$ people had served as homeroom teachers of class 1 , three $(5.6 \%)$ people had served as homeroom teachers of class 2 , three $(5.6 \%)$ people had served as homeroom teacher 3 , seven $(13 \%)$ people had served as homeroom teacher 4 th, $13(24.1 \%)$ people had served as homeroom teacher class 5, $12(22.2 \%)$ people had served as homeroom teacher 6 , and four $(7.4 \%)$ people had worked as teachers in other fields. Based on these data, it can be identified that the majority of teachers were aged 41 years and over, and the majority have been teachers for more than 10 years. This represents that although the majority of their age is old, the spirit is still young. This also reflects the high need to add knowledge and skills to be able to teach music well.

\subsection{Research Procedure}

The researchers planned and implemented several stages of training that are always reflected as an inseparable part of the action research process. There were three major stages, namely the pre-action, action, and post-action stages. The pre-action stage consisted of survey activities and initial data analysis. The action stage consisted of the critical and reflective actions. The post-action stage consisted of evaluation of the results of activities. The action stage produced five critical-reflective steps in the process of improving teacher competency, namely the stage of growing motivation, identifying knowledge and ways of teaching music, adding tools to teach music, building communication through social media, and activating in scientific forums. In the post-action stage, the researchers conduct analysis, evaluation, and discussions related to the findings from the series of training activities.

Throughout the training, the teachers were observed and assigned to fill out a survey. The survey consisted of questions and statements on a Likert and Gutman scale. This was used to identify the teacher's perception of various matters related to the problem of music education and training activities. Open questions were also given in surveys at each stage of the activity. Google Docs was used as a tool for conducting the surveys. The teachers were more familiar with this application because it can be accessed via a smartphone so that it was easier to complete every survey. Google Doc is also a simple survey tool for researchers to collect research data (Abrams, 2019; Gugino,
2017; Lin, Chang, Hou, \& Wu, 2016; Travis, 2010).

\section{Results}

The three major stages to improve teacher competence in teaching music were implemented in this training. The five critical-reflective stages were also applied in a structured manner, accompanied by small treatments at each stage based on the teachers' needs and the results of reflection. All stages are explained in detail in the following description.

\subsection{Pre-Action Analysis}

54 teachers were surveyed to find out a number of discussions related to their activeness in teaching music, the type of material being taught, the training schedule from the government, and their motivation to attend the training. When asked, "Are you active in teaching music?" A total of $11(20.4 \%)$ teachers answered "Yes," four (7.4\%) teachers answered "No," and 39 (72.2\%) teachers answered "Sometimes." Thus, the majority of teachers lacked activeness in teaching music. When explored further on their reasons, $53(98.1 \%)$ teachers said that they had problems. One teacher said, "I don't understand melody and scale." Another teacher claimed to lack mastery of song notation. There were also teachers who had problems understanding tempo and rhythm. There were a many fundamental problems in music material that were not yet understood by the teacher, especially in the basic theories of music and understanding of the elements of music.

Under these conditions, the researchers traced back to the teacher capacity building program carried out by the local government. When the teachers were asked, "Does the local education office carry out elementary school music teacher competency development program in the last five years?" As many as 27 (50\%) teachers answered "Never," nine (16.7\%) answered "Yes," 13 (24.1\%) answered "Rarely," one $(1.9 \%)$ answered "Frequently," and four (7.4\%) answered "Very Frequently." After further exploration, the teacher's answer led to the finding that only a small number of teachers were involved in the training program for the development of elementary school music teacher competencies organized by the local government. Based on the condition, the researchers tried to identify their motivation to take music teaching training through a survey on a Likert scale (Strongly Disagree - Disagree - Rather Disagree - Agree - Strongly Agree). Their answers are presented in Figure 2 and 3.

The teachers were asked, "Do you agree that the elementary music teacher training program is carried out continuously every year?" Their answers showed that eight $(14.8 \%)$ teachers agreed and $45(83.3 \%)$ teachers strongly agreed. Only one $(1.9 \%)$ teacher strongly disagreed if elementary school music teacher training is held every year. 


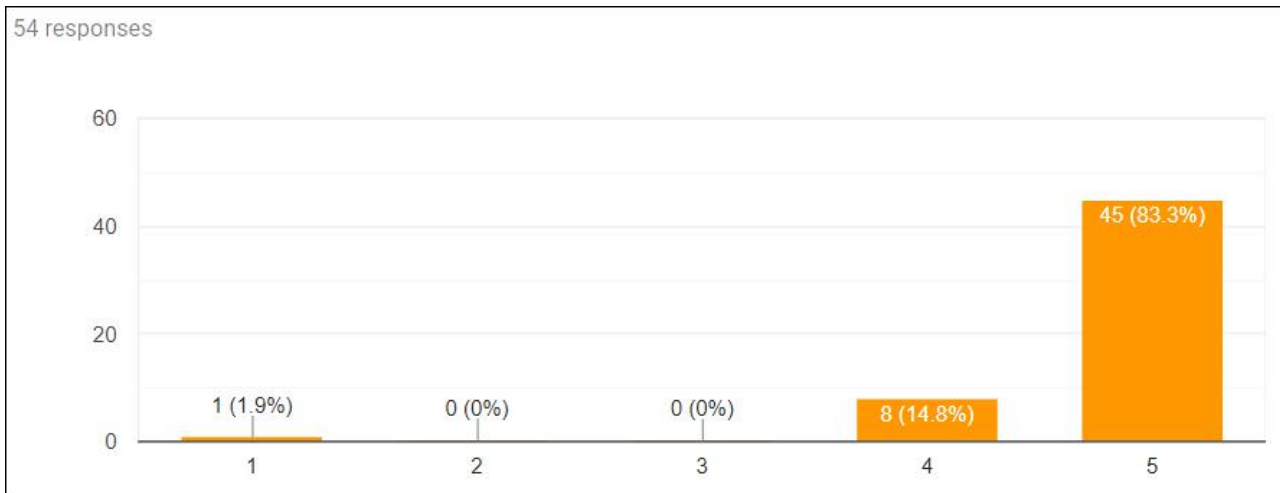

Figure 2. Results of survey of teachers on the training program for elementary school music teachers

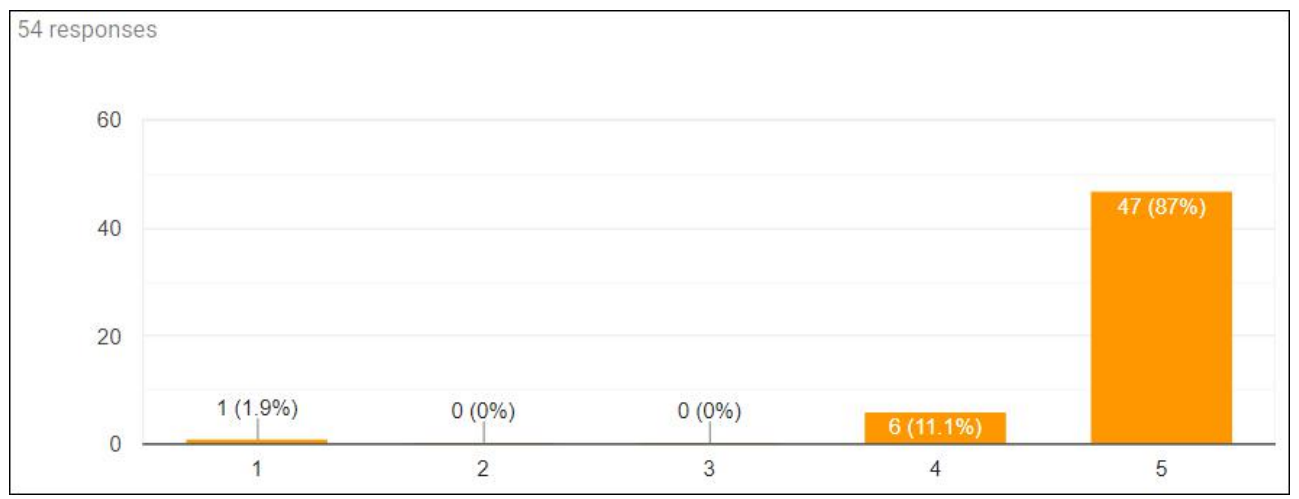

Figure 3. Results of survey of teachers on the collaboration of lecturers and teachers in teaching music

They were also asked, "Do you agree if the lecturer collaborates with the teacher to develop music learning in elementary school?". Their answers showed that as many as six $(11.1 \%)$ teachers agreed and $47(87 \%)$ teachers strongly agreed. Only one (1.9\%) teacher strongly disagreed.

Based on the search results above, it was concluded that the majority of teachers had not yet mastered the basic theory of music which had an impact on the lack of good teaching of music. They also lack training in self-improvement from the government. However, the positive side is that the majority of teachers still have high motivation to participate in training programs to improve their self-competence. Therefore, teachers are involved in this training.

\subsection{Action of Competence Training in Teaching Music}

There were five steps applied to improve teacher competence in teaching music. Specifically, the researchers did a reflection to analyze what was needed by the teacher and needed to be addressed. This critical-reflective thinking process took place in cycles at each stage of the training. The following are the five stages that are applied to the trainees.

\subsubsection{Step 1: Growing Motivation}

The teachers were motivated to improve their desire to master musical material and how to teach it better. One way to motivate was to provide an explanation of the impact that they could have had if they taught music with the wrong method and not mastering the material (J Julia, Arif Hakim, et al., 2019). We gave an example if their own children who are learning by music by teachers who do not have competence in music, which can result in low vocal accuracy so that the children would sing in poor condition for the rest of their lives. Another example case was children may be tone blind and rhythm blind because their musical sense is not well formed through formal education in elementary school. The researchers also provided an illustration through video shows about children who were gifted and given the right education so as to produce children who are skilled in playing musical instruments or singing. Also explained to them is the possibility of forming a happy attitude of cooperation in children because they are accustomed to collaborating in playing musical instruments in an ensemble.

One example of a good presentation to motivate them was to show a video of a child who was born blind named Nobuyuki Tsujii. The child was given proper music education with the full support of his parents and teachers so that he eventually became a world-class pianist. One of the videos on YouTube which is used as a media to motivate teachers is a video titled "Miracle Pianist Nobuyuki Tsujii" which was accessible at https://www.youtube.com/watch?v=jA_AQSqhJ6A. It was also asserted that there is no reason for teachers not to make 
their students into valuable human beings in the world. There are many ways that can be taken to bring students into human beings who are able to reach the peak of their competence. Proper music education can be one of the ways to reach that peak.

\subsubsection{Step 2: Rectifying Knowledge and Ways of Teaching}

The researchers identified the extent of the teachers' knowledge and understanding of music including how to teach music. The teachers brought the proper knowledge and also the wrong knowledge as a result of music education previously obtained. The teachers did not understand well that their voice as a model in teaching songs could influence the process of forming vocal accuracy, especially female voice (Yarbrough, Green, Benson, \& Bowers, 1991). In other words, if the teacher's voice when teaching a song is not good or the vocal pitch is not perfect, then students can also form a vocal pitch that is also not good. Meanwhile, the teachers had a habit of teaching songs with their own voice even though their vocal pitch was not good. Therefore, they were given an explanation and an understanding of the impact of the way they teach the songs they used to do. The teachers were trained in how to teach songs using the media or recorded songs as their sound models. The researchers gave examples of the latest songbook that supported teaching in this way, where one book is equipped with audio both in the form of vocals and musical accompaniment, and in the form of karaoke. They were also shown free websites that provided songs for children which are accompanied by accompaniment in the form of karaoke, such as https://www.singing-bell.com. This site could be used as a medium for teaching songs to students with examples of good vocal pitch.

The teachers also did not understand well what was meant by the numbers in the time signature such as $3 / 4$ or 4/4. They faced difficulties with the practice. Meanwhile, the music curriculum states that the teacher must teach students about the types of music rhythm. Therefore, they were reinforced about rhythm that the numbers above show the number of beats in one bar, and the numbers below show the notes that are used as a benchmark in one beat. The explanation was completed by replaying the types of notes and reading them, and demonstrating several types of songs in different rhythms. They showed a change in basic knowledge of music. However, the majority of the teachers still complained about how to teach better and easier for them in music material related to the tempo and melody of songs. We developed the training by providing Android-based tools, because all of the teachers were Android-based smartphone users.

\subsubsection{Step 3: Adding Tools to Teach Music}

The teachers were surveyed to find out how far they were using technology to teach music. When asked, "What technology do you currently use in teaching music?" Their answers indicate that $24(44.4 \%)$ teachers already used Android-based applications, six (11.1\%) teachers used computer software, and 24 (44.4\%) teachers had not yet used technology. Thus, some teachers had used technology to teach music, and some had not yet used technology. In order to have the same understanding, the researchers informed several Android-based music applications and all of the teachers were instructed to install the same application even though there were many similar applications in the Google Play Store. We chose the Perfect Piano application, as shown in Figure 4 to train teachers in teaching song melodies, and used the Metronome Beats application as shown in Figure 5 to train teachers in teaching tempo.

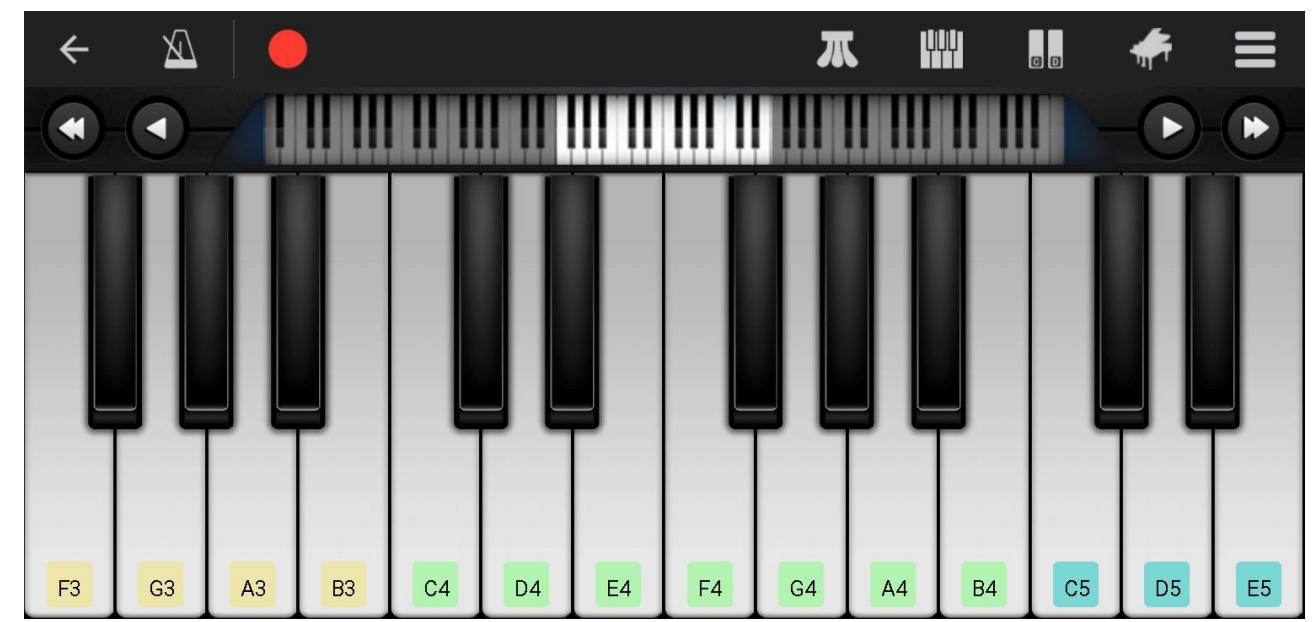

Figure 4. Perfect Piano Application (Pro version) 


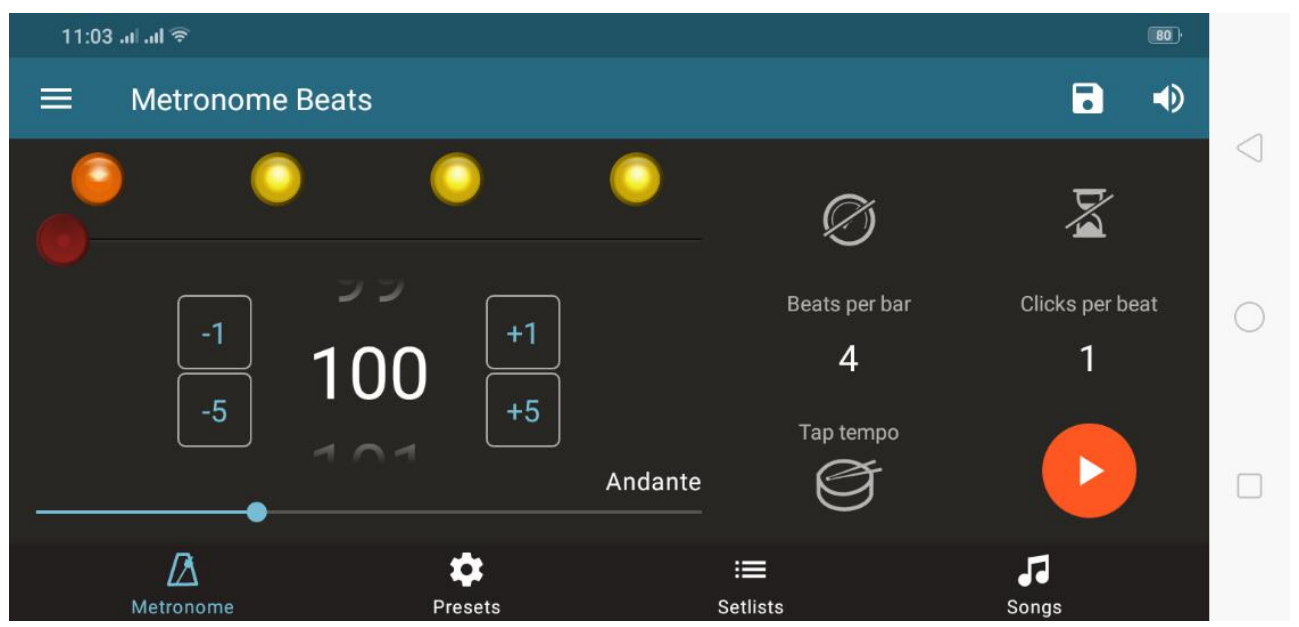

Figure 5. Metronome Beats Application (Pro Version)

Examples were given on how to use these applications optimally in the teaching process. Starting from connecting the smartphone to loudspeakers, connecting the smartphone to the laptop through the Screen Mirroring application so that everything played on the smartphone can also be seen by students through the projector, to see the operation of the application and find out the functions in each menu available in the application. The teachers were eager to follow every step given because these applications were basically easy. It was only the lack of information or ignorance about the existence of these applications that made teachers not use technology in the teaching process. It was emphasized that to get the latest information about music education, they were advised to attend scientific meetings such as seminars or workshops and no need to wait for programs from the government which incidentally sometimes has unclear scheduling. The results of this stage led the teachers to have ideas to discuss in social media groups, so that every problem they faced could be directly communicated on social media.

\subsubsection{Step 4: Building Communication through Social Media}

The teachers created discussion groups in the WhatsApp application and they named it Grup Pelatihan Seni (Art Training Group). In this group, they discussed a variety of ideas such as reviewing training materials, reporting the results of implementing music teaching in their schools, discussing plans participation in similar activities if held again, and others. Some of them also expressed their regret because there was a series of training activities that they could not take part in due to a clash of activities at their institution. One of the topics discussed was certificates. From the discussions, one of the factors that motivated them to attend the training was to get a certificate as a trainee. For them, certificates were supporting elements for the evidence of annual reports as civil servants, that they are actively developing themselves. The teachers also expressed that there were still many issues to be discussed along with the findings of music learning problems that occurred in their respective schools. Seeing the activeness of the teachers, a seminar was added as the final part of the training. Through the seminar, they could discuss directly with other music experts. They were also recommended to take part in other scientific forums with the aim to always update information and the latest developments about music education.

\subsubsection{Step 5: Activating in Scientific Forums}

To build a culture and community of teachers who are active in developing music education, the teachers were directed to actively participate in seminars that would be held in the institutions. We sent formal invitations to the teachers through their institutions to attend educational seminars that were held not far from this training site. The teachers were not forced to attend the seminar, but they were invited and the researchers wanted to see the extent of the teachers' interest in adding information and reinforcing the problem of teaching music. Several teachers were present but several others were unable to attend due to the clash of activities at their school. Through the seminar, the teachers actively participated by conducting question-and-answer sessions with the seminar speakers, including the researchers who also served as speakers at the seminar.

Some of the topics that the teachers asked were the latest music learning problems based on their findings after participating in the series of training activities. One teacher said that he had changed the way he taught music especially in teaching songs. He used to teach by oral method, but now it had changed by using media or model songs from recordings. He faced problems with the vocal pitch of third grade elementary school children who were still changing or unstable. Another teacher asked how to breathe when singing certain songs that use fast tempo or the melody phrase is quite long. There were also teachers who asked about vocal pitch whether influenced by the speech accents of different children from the region. One teacher also asked a quite interesting problem, namely how to set the 
basic tone of the song when students used to sing with diatonic tonality and then moved to songs that had a pentatonic tone, such as folklore songs from their own area. All questions from the teacher were discussed and given examples in practice. In this step, the trainees had shown changes in the way they teach music and had fostered a critical attitude in the music teaching process.

\section{Discussion and Conclusions}

In the post-action stage, the survey was conducted again to identify how much they had improved their competencies and how they teach music, including how they were interested in going forward to participate in similar activities for personal development. The survey results showed that all teachers $(100 \%)$ claimed to have changed their way of teaching music. The use of media became a major requirement in the process of teaching music (Thibeault, 2012). Some teachers stated that there were difficulties with the provision of learning media because the schools had not yet had complete facilities, but some teachers dealt with it with their own efforts or from their own capital. Their competence in the practice of singing or playing musical instruments did not develop, but their knowledge in the basic theory of music to teach songs had developed, including the practice of making simple musical accompaniment using different time signatures.

The survey results about their interests also showed that all of the teachers $(100 \%)$ agreed to participate in similar activities in the following years. When asked what types of activities they needed, they responded in a variety of ways. Some teachers proposed training activities to teach musical instruments such as angklung and piano. Some teachers suggested training songs for competitions that are routinely carried out between elementary schools in their area. There were teachers who proposed training in the use of applications supporting music teaching. There were also teachers who proposed the reinforcement of the material to read beam notation and number notation commonly used in the music curriculum in Indonesia. The proposed activities given by the teachers provided a clear picture that they still needed a process of competence improvement that also showed their considerable interest in continuing to develop themselves.

Each stage and step of the activities had significant impacts on the teachers' skills and knowledge in teaching music. The teachers were motivated to do meaningful music teaching after appreciating the motivational builder video in the early stages. They concretely saw how an invalid child develops into a successful human figure in his music career because he obtained proper music education. They realized that giving attention and follow every development of each student is very important (Dobbs, Arnold, \& Doctoroff, 2004; Pallini, Vecchio, Baiocco, Schneider, \& Laghi, 2019; Russ, 2018). The teachers' knowledge also increased and stabilized after going through the rectification stage. Their initial knowledge of how to teach music that was accustomed to using the oral method changed into using audio-visual media. The understanding of musical elements was quite developed, so they could know, for example, the meaning of the differences in time signatures, diatonic and pentatonic tonality, and tempo.

The teachers' vital improvement in knowledge and skills also lies in the use of Android-based music applications. The teachers could easily recognize various music applications and how to use them after being given comprehensive information through live shows accompanied by demonstrations. In other words, music teaching assisted by a touch of technology made it easier for teachers (J Julia, Iswara, \& Supriyadi, 2019), even though the teachers' skills (musical competence) were not very good. Vocal teaching was assisted by the Piano application and tempo teaching was assisted by the Metronome application. This means that music learning is developed with the touch of media (J Julia, Kurnia, Isrokatun, Wulandari, \& Aisyah, 2019; Scheid, 2014). This condition also illustrated that in the teaching process, it is not only the skills and technology that are the key to success, but also the strategies used by teachers (J Julia, Arif Hakim, et al., 2019; Peter R Webster, 1998; Peter R. Webster, 2002). They also even wanted other training that specifically broadens their horizons in using applications for music learning.

The final part of the training showed that the teachers had built a good music teaching community by creating discussion groups to communicate through social media. The establishment of this communication and discussion channel had opened opportunities for teachers to continue to update their knowledge regularly because information could be shared here. They could also give advice to each other and open up new problems that occurred in their schools. This way, their knowledge became solid to face and solve every problem of teaching music. Coupled with their active participation in scientific forums such as seminars, their knowledge and skills in teaching music became more solid. Their awareness was also increasingly wide open that self-development must be carried out through various means including attending scientific forums. Through scientific forums, in addition to obtaining answers to their own problems, they also obtain a new understanding of the problems of other teachers discussed in scientific forums. Thus, the teachers' understanding became more mature and stable. In line with the results of previous research, training can improve the teachers' ability in teaching music (Delport \& Mufute, 2010a; Dogani, 2008; Hallam et al., 2009; J Julia, T Supriyadi, et al., 2019).

In conclusion, all the steps taken in current the action research provided answers to the research questions. The answer to the first question, the results of the training showed that the teachers were able to develop their knowledge of the basic theories of music and knowledge of 
several applications that support music teaching, and they were able to improve their skills in teaching music. Then answer to the second question is that the teachers were willing and able to change the way they teach music. Teachers who were familiar with the oral method changed the way of using teaching media, ranging from the use of audio-visual tools, to the use of Android-based music applications. Thus, the non-specialist music teacher training in five critical-reflective steps in this action research was able to improve the teachers' competence in teaching music in elementary schools.

\section{Suggestions}

This research concluded that teachers lacked programs for self-development. Therefore, the government or the local education office should regularly conduct training programs for elementary school music teachers. The government should also review the teachers' obligations in teaching, because on the one hand they are required to develop themselves, but on the other hand, the teachers cannot leave school when there are opportunities to attend training because they are preoccupied with very busy teaching hours.

\section{Acknowledgments}

We extend our gratitude to the Lembaga Penelitian dan Pengabdian kepada Masyarakat (LPPM, Institute of Research and Community Service) of Universitas Pendidikan Indonesia for funding this activity with the Decree of Rector Number 5493/UN40/KP/2019. We are also grateful to the Yayasan Sumedang Motekar for helping with the training.

\section{REFERENCES}

[1] Abrahams, F. (2005). Transforming classroom music instruction with ideas from critical pedagogy. Music Educators Journal, 92(1), 62-67.

[2] Abrams, Z. I. (2019). Collaborative writing and text quality in Google Docs. Language Learning \& Technology, 23(2), $22-42$.

[3] Abril, C. (2011). Music, movement, and learning. In MENC Handbook of Research on Music Learning: Applications: Oxford University Press.

[4] Adams, P., \& Townsend, D. (2014). From action research to collaborative inquiry: A framework for researchers and practitioners. Education Canada, 54(5), 12-15.

[5] Ado, K. (2013). Action research: Professional development to help support and retain early career teachers. Educational Action Research, 21(2), 131-146.
[6] Al-Mahdi, O. (2019). Action Research and Teachers' Professional Development: Examples and Reflections. International Educational Research, 2(3), p37-p37.

[7] Amin, M. Z. M., Rashid, R. A., \& Teh, K. S. M. (2019). Investigating Issues and Challenges in Employing Action Research for Teacher Training in Malaysian Context. International Journal of Education and Practice, 7(1), 30-40.

[8] Anderson, S. A., \& Denson, G. L. (2015). Preparing the successful urban music educator: The need for preservice and in-service development. Music Educators Journal, 101(4), 35-40.

[9] Apriani, L., \& Julia, J. (2019). Digital application in teaching musical traditional instrument for children. Paper presented at the Journal of Physics: Conference Series.

[10] Bakker, A. B. (2005). Flow among music teachers and their students: The crossover of peak experiences. Journal of vocational behavior, 66(1), 26-44.

[11] Ballantyne, J. (2006). Reconceptualising preservice teacher education courses for music teachers: The importance of pedagogical content knowledge and skills and professional knowledge and skills. Research Studies in Music Education, 26(1), 37-50.

[12] Ballantyne, J. (2007). Integration, contextualization and continuity: three themes for the development of effective music teacher education programmes. International Journal of Music Education, 25(2), 119-136.

[13] Barrett, M. S., Zhukov, K., \& Welch, G. F. (2019). Strengthening music provision in early childhood education: a collaborative self-development approach to music mentoring for generalist teachers. Music education research, 21(5), 529-548. doi:10.1080/14613808.2019.1647154

[14] Blackburn, L. (2000). The work and inspiration of master teachers: Zoltan Kodály and Carl Orff. In: Moscow: Educational Consultants International.

[15] Brand, M., \& Burnsed, V. (1981). Music abilities and experiences as predictors of error-detection skill. Journal of Research in Music Education, 29(2), 91-96.

[16] Byo, J. L. (1993). The influence of textural and timbral factors on the ability of music majors to detect performance errors. Journal of Research in Music Education, 41(2), 156-167.

[17] Byo, J. L. (1997). The effects of texture and number of parts on the ability of music majors to detect performance errors. Journal of Research in Music Education, 45(1), 51-66.

[18] Campbell, L., Campbell, B., \& Dickinson, D. (1999). Teaching and Learning through Multiple Intelligences (second edition ed.). Boston: Allyn and Bacon.

[19] Canrinus, E. T., Bergem, O. K., Klette, K., \& Hammerness, K. (2017). Coherent teacher education programmes: Taking a student perspective. Journal of Curriculum Studies, 49(3), 313-333.

[20] Carver, M. (2017). Knowledge Transfer: Indigenous African Music In The South African Music Curriculum. African Music, 10(3).

[21] Choksy, L. (2001). Teaching music in the twenty-first century: Prentice Hall. 
[22] Collins, D. L. (1993). Teaching choral music: Prentice Hall Englewood Cliffs, NJ.

[23] Creswell, J. W. (2015). Educational Research: Planning, Conducting, and Evaluating Quantitative and Qualitative Research, Enhanced Pearson eText with Loose-Leaf Version--Access Card Package. United Kingdom: Pearson Education, Inc.

[24] Delport, A., \& Mufute, J. (2010a). Training the non-specialist music teacher: insights from a Zimbabwean case study. Journal of the Musical Arts in Africa, 7(1), 1-15. doi:10.2989/18121004.2010.619689

[25] Delport, A., \& Mufute, J. (2010b). Training the non-specialist music teacher: insights from a Zimbabwean case study. Journal of Musical Arts in Africa, 7(1), 1-15.

[26] Dibane, Z. (2018). The Professional Mathematics Teacher Identity of non-specialist primary school mathematics teachers. University of Pretoria,

[27] Dobbs, J., Arnold, D. H., \& Doctoroff, G. L. (2004). Attention in the preschool classroom: the relationships among child gender, child misbehavior, and types of teacher attention. Early Child Development and Care, 174(3), 281-295. doi:10.1080/0300443032000153598

[28] Dogani, K. (2008). Using reflection as a tool for training generalist teachers to teach music. Music education research, 10(1), 125-139. doi:10.1080/14613800701871595

[29] Dotger, B., Dekaney, E., \& Coggiola, J. (2019). In the limelight: utilizing clinical simulations to enhance music teacher education. Research Studies in Music Education, 41(1), 99-116.

[30] Edelman, P. B. (2016). Cooperating music teachers' opinions regarding the importance of selected traits as predictors of successful student teaching experiences.

[31] Elliott, D. J. (1995). Music Matters A New Philosophy of Music Education. New York: Oxford University Press.

[32] Elliott, J. (2015). Educational action research as the quest for virtue in teaching. Educational Action Research, 23(1), 4-21.

[33] Flolu, J. (2004). Music teacher education in Ghana: Training for the churches or the schools? Sounds of Change-Social and Political Features of Music in Africa. Stockholm: SIDA, 164-179.

[34] Furtado, L., \& Anderson, D. (2012). The reflective teacher leader: An action research model. Journal of School Leadership, 22(3), 531-568.

[35] Garnett, J. (2013). Enterprise pedagogy in music: an exploration of multiple pedagogies. Music education research, 15(1), 1-18.

[36] Georgii-Hemming, E., \& Westvall, M. (2010). Teaching music in our time: student music teachers' reflections on music education, teacher education and becoming a teacher. Music education research, 12(4), 353-367.

[37] Gordon, S. P., \& Solis, R. D. (2018). Teacher Leaders of Collaborative Action Research: Challenges and Rewards. ie: inquiry in education, 10(2), 3 .

[38] Groulx, T. J. (2016). Perceptions of course value and issues of specialization in undergraduate music teacher education curricula. Journal of Music Teacher Education, 25(2), 13-24.

[39] Gugino, J. (2017). Using Google Docs to Enhance the Teacher Work Sample: Building e-Portfolios for Learning and Practice. Journal of Special Education Technology, 33(1), 54-65. doi:10.1177/0162643417729135

[40] Hallam, S., Burnard, P., Robertson, A., Saleh, C., Davies, V., Rogers, L., \& Kokatsaki, D. (2009). Trainee primary-school teachers' perceptions of their effectiveness in teaching music. Music education research, 11(2), 221-240.doi:10.1080/14613800902924508

[41] Haston, W., \& Leon-Guerrero, A. (2008). Sources of pedagogical content knowledge: Reports by preservice instrumental music teachers. Journal of Music Teacher Education, 17(2), 48-59.

[42] Heil, D. (2005). The internet and student research: Teaching critical evaluation skills. Teacher Librarian, 33(2), 26.

[43] Henderson, L. (2017). 'Someone had to have faith in them as professionals': an evaluation of an action research project to develop educational leadership across the early years. Educational Action Research, 25(3), 387-401.

[44] Hennessy, S. (2017). Approaches to increasing the competence and confidence of student teachers to teach music in primary schools. Education 3-13, 45(6), 689-700. doi:10.1080/03004279.2017.1347130

[45] Hernández-Bravo, J. R., Cardona-Moltó, M. C., \& Hernández-Bravo, J. A. (2016). The effects of an individualised ICT-based music education programme on primary school students' musical competence and grades. Music education research, 18(2), 176-194.doi:10.1080/14613808.2015.1049255

[46] Hines, M. B., \& Conner-Zachocki, J. (2015). Using practitioner inquiry within and against large-scale educational reform. Teacher Development, 19(3), 344-364.

[47] Jarvin, L., \& Subotnik, R. F. (2010). Wisdom from conservatory faculty: Insights on success in classical music performance. Roeper Review, 32(2), 78-87.

[48] Jayakumar, R. (2016). Opinion of the university teachers towards educational television programmes. American Journal of Education and Learning, 1(1), 45-52.

[49] Julia, J., Hakim, A., \& Fadlilah, A. (2019). Shifting Primary School Teachers Understanding of Songs Teaching Methods : An Action Research Study in Indonesia. International Journal of Education and Practice, 7(3), 158-167.doi:http://dx.doi.org/10.18488/journal.61.2019.73.1 58.167

[50] Julia, J., \& Isrokatun, I. (2019). Technology Literacy and Student Practice: Lecturing Critical Evaluation Skills. International Journal of Learning, Teaching and Educational Research,

114-130.doi:https://doi.org/10.26803/ijlter.18.9.6

18(9),

[51] Julia, J., Isrokatun, I., Pramajati, H., Sukaesih, N. S., \& Aisyah, I. (2019). Improving the Song Notation Reading Comprehension and Skill of Prospective Elementary School Teachers: An Action Research Study in Indonesia. Universal Journal of Educational Research, 7(10), 2057-2067. doi:10.13189/ujer.2019.071003

[52] Julia, J., Iswara, P. D., \& Supriyadi, T. (2019). Redesigning 
and Implementing Traditional Musical Instrument in Integrated Technology Classroom. International Journal of Emerging Technologies in Learning, 14(10), 75-87. doi:https://doi.org/10.3991/ijet.v14i10.10197

[53] Julia, J., Kurnia, D., Isrokatun, I., Wulandari, H., \& Aisyah, I. (2019). The use of the Synthesia application to simplify Angklung learning. Paper presented at the Journal of Physics: Conference Series.

[54] Julia, J., Supriyadi, T., \& Iswara, P. (2019). Using Android-based applications to support elementary school teachers to teach songs. Paper presented at the Journal of Physics: Conference Series.

[55] Kane, R. G., \& Chimwayange, C. (2014). Teacher action research and student voice: Making sense of learning in secondary school. Action Research, 12(1), 52-77.

[56] Katahira, K., Abla, D., Masuda, S., \& Okanoya, K. (2008). Feedback-based error monitoring processes during musical performance: an ERP study. Neuroscience research, 61(1), $120-128$.

[57] Kemmis, S., \& McTaggart, R. (2005). Participatory Action Research: Communicative Action and the Public Sphere. In N. K. Denzin \& Y. S. Lincoln (Eds.), The SAGE handbook of qualitative research (3rd ed) (pp. 556-604). Thousand Oaks, CA: Sage.

[58] Kemmis, S., McTaggart, R., \& Nixon, R. (2014). The action research planner: Doing critical participatory action research: Springer Science \& Business Media.

[59] Kholodnaya, M. (2002). Intelligence as a form of mental experience. Intelligence Psychology: paradoxes of research. St. Petersburg: Peter.

[60] Kiss, T. (2016). School-based teacher learning: A reflective approach. Journal of Nusantara Studies (JONUS), 1(2), $50-62$.

[61] Kovalev, D. A., Khussainova, G. A., Balagazova, S. T., \& Zhankul, T. (2016). Formation of Various Competencies in the Process of Training the Future Music Teachers at the Present Stage. International Journal of Environmental and Science Education, 11(11), 4175-4183.

[62] Kuebel, C. (2017). Preparation, continuing education, and professional Development of instrumental music majors teaching elementary general music. Case Western Reserve University,

[63] Lasauskiene, J., \& Yang, Y. (2017). Developing and renewing music teacher competences: prospects and challenges. New Trends and Issues Proceedings on Humanities and Social Sciences, 4(8), 225-233.

[64] Legette, R. M. (2013). Perceptions of early-career school music teachers regarding their preservice preparation. Update: Applications of Research in Music Education, 32(1), 12-17.

[65] Legette, R. M., \& McCord, D. H. (2014). Pre-service music teachers perceptions of teaching and teacher training. Contributions to Music Education, 163-176.

[66] Lin, Y.-T., Chang, C.-H., Hou, H.-T., \& Wu, K.-C. (2016). Exploring the effects of employing Google Docs in collaborative concept mapping on achievement, concept representation, and attitudes. Interactive Learning
Environments,

1552-1573. doi:10.1080/10494820.2015.1041398

24(7),

[67] Louise, E., \& Crawford, R. (2016). The impact of Blended Learning and Team Teaching in tertiary pre-service music education classes. Journal of University Teaching \& Learning Practice, 13(3), 5.

[68] Maidhof, C., Rieger, M., Prinz, W., \& Koelsch, S. (2009). Nobody is perfect: ERP effects prior to performance errors in musicians indicate fast monitoring processes. PLoS One, 4(4), e5032.

[69] Matonis, V. (2007). Changing competences and professional limits of music teacher activities. Pedagogika(86), 111-116.

[70] Maulana, A., \& Julia, J. (2019). Using Pazia Angklung application in understanding song scores. Paper presented at the Journal of Physics: Conference Series.

[71] McPherson, G. E., \& McCormick, J. (2006). Self-efficacy and music performance. Psychology of Music, 34(3), 322-336.

[72] McQuillan, P. J., Welch, M. J., \& Barnatt, J. (2012). In search of coherence:'Inquiring'at multiple levels of a teacher education system. Educational Action Research, 20(4), 535-551.

[73] McTaggart, R. (1994). Participatory action research: Issues in theory and practice. Educational Action Research, 2(3), 313-337.

[74] Miksza, P., Roeder, M., \& Biggs, D. (2010). Surveying Colorado band directors' opinions of skills and characteristics important to successful music teaching. Journal of Research in Music Education, 57(4), 364-381.

[75] Millican, J. S. (2016). Describing preservice instrumental music educators' pedagogical content knowledge. Update: Applications of Research in Music Education, 34(2), 61-68.

[76] Mitits, L. (2018). Multilingual Students in Greek Schools: Teachers' Views and Teaching Practices. Journal of Education and e-Learning Research, 5(1), 28-36.

[77] Morrow, W. (2007). Learning to teach in South Africa. Cape Town: HSRC Press.

[78] Pallini, S., Vecchio, G. M., Baiocco, R., Schneider, B. H., \& Laghi, F. (2019). Student-Teacher Relationships and Attention Problems in School-Aged Children: The Mediating Role of Emotion Regulation. School Mental Health, 11(2), 309-320. doi:10.1007/s12310-018-9286-Z

[79] Parker, E. C., Bond, V. L., \& Powell, S. R. (2017). A Grounded Theory of Preservice Music Educators' Lesson Planning Processes Within Field Experience Methods Courses. Journal of Research in Music Education, 65(3), 287-308.

[80] Pelton, R. P. (2010). Action research for teacher candidates: Using classroom data to enhance instruction: $R \& L$ Education.

[81] Péter, É. (2013). Competence based music teaching. Studia Universitatis Babes-Bolyai-Musica, 58(2), 143-149.

[82] Rohwer, D., \& Henry, W. (2004). University teachers' perceptions of requisite skills and characteristics of effective music teachers. Journal of Music Teacher Education, 13(2), 
$18-27$.

[83] Russ, R. S. (2018). Characterizing teacher attention to student thinking: A role for epistemological messages. Journal of Research in Science Teaching, 55(1), 94-120.

[84] Scheid, M. (2014). Music education - privately, personally and professionally The school subject of Music, digital media and tools. Education Inquiry, 5(2), 23255.doi:10.3402/edui.v5.23255

[85] Sheldon, D. A. (2001). Peer and Cross-Age Tutoring in Music: Peer and cross-age tutoring allows music students to help each other and benefits both the music teacher and the students themselves. Music Educators Journal, 87(6), 33-38.

[86] Shulman, L. S., \& Wilson, S. M. (2005). The wisdom of practice: Essays on teaching, learning, and learning to teach: Jossey-Bass San Francisco.

[87] Si Millican, J. (2008). A new framework for music education knowledge and skill. Journal of Music Teacher Education, 18(1), 67-78.

[88] Sloboda, J. A. (2000). Individual differences in music performance. Trends in cognitive sciences, 4(10), 397-403.

[89] Sullivan, S., \& Glanz, J. (2013). Supervision that improves teaching and learning: Strategies and techniques: Corwin Press.

[90] Teachout, D. J. (1997). Preservice and experienced teachers' opinions of skills and behaviors important to successful music teaching. Journal of Research in Music Education, 45(1), 41-50.

[91] Teplov, B. M. (1985). Psychology of individual differences. Selected Works, 2, 211 - 223.

[92] Thibeault, M. D. (2012). From compliance to creative rights in music education: rethinking intellectual property in the age of new media. Music education research, 14(1), 103-117. doi:10.1080/14613808.2012.657165

[93] Thomasian, M. (2007). The Wisdom of Practice: Essays on Teaching, Learning, and Learning to Teach, by Lee S. Shulman. Journal of Catholic Education, 11(2), 250-252.

[94] Tomlinson, M. (2012). Transformative music invention: interpretive redesign through music dialogue in classroom practices. Australian Journal of Music Education, 1, 42-56.

[95] Travis, L. (2010). One of Many Free Survey Tools: Google Docs. Journal of Electronic Resources in Medical Libraries, 7(2), 105-114. doi:10.1080/15424065.2010.482902

[96] Utama, A., \& Julia, J. (2019). The stability of Pianika's tempo in elementary school students. Paper presented at the Journal of Physics: Conference Series.

[97] vanOostveen, R. (2017). Purposeful Action Research: Reconsidering Science and Technology Teacher Professional Development. College Quarterly, 20(2), n2.

[98] Vasilyeva, N. (2006). Development of music performance competence as a factor of professional training of the future music teachers in the context of pedagogical college. Problems of history, philology and culture, 17, 171-176.

[99] Vicente-Nicolás, G., \& Mac Ruairc, G. (2014). Music activities in primary school: students' preferences in the Spanish region of Murcia. Music education research, 16(3), 290-306. doi:10.1080/14613808.2014.912261

[100] Vo, K. A. T., Pang, V., \& Lee, K. W. (2018). Teaching practicum of an English teacher education program in Vietnam: From expectations to reality. Journal of Nusantara Studies (JONUS), 3(2), 32-40.

[101] Webster, P. R. (1998). Young children and music technology. Research Studies in Music Education, 11(1), 61-76.

[102] Webster, P. R. (2002). Music Technology and the Young Child. In L. Bresler \& C. M. Thompson (Eds.), The Arts in Children's Lives: Context, Culture, and Curriculum (pp. 215-236). Dordrecht: Springer Netherlands.

[103] Wexler, M. K. (2009). A comparative survey of goals and strategies of college music performance teachers across instrumental groups: Teachers College, Columbia University.

[104] Wiggins, J. (2007). Authentic practice and process in music teacher education. Music Educators Journal, 93(3), 36-42.

[105] Wright, R., \& Kanellopoulos, P. (2010). Informal music learning, improvisation and teacher education. British Journal of Music Education, 27(1), 71-87.

[106] Yarbrough, C., Green, G., Benson, W., \& Bowers, J. (1991). Inaccurate singers: An exploratory study of variables affecting pitch-matching. Bulletin of the Council for Research in Music Education, 23-34. 